A Klinik für Handchirurgie, Rhön-Klinikum AG, Bad Neustadt an der Saale', a

Semmelweis Egyetem, Rácz Károly Doktori Iskola² és a Semmelweis Egyetem, Általános Orvostudományi Kar, Ortopédiai Klinika, Budapest ${ }^{3}$ közleménye

\title{
A kéztő avascularis csontnekrózisainak kialakulása Irodalmi áttekintés
}

\author{
DR. KASZAP BALÁZS'1,2, DR. SKALICZKI GÁBOR ${ }^{3}$
}

\section{ÖSSZEFOGLALÁS}

A kéztő avascularis csontnekrózisainak kialakulásáért a mai tudásunk szerint mindenekfelett a terület vérellátási zavara felelős, amely önmagában is multifaktoriális eredetü, de számtalan egyéb faktor is hozzájárulhat a kialakuláshoz. A pontos etiológia több mint egy évszázada tisztázatlan. A kéztő messze leggyakrabban érintett csontja a holdascsont (morbus Kienböck), amivel számtalan publikáció foglalkozik a szakirodalomban. A többi kéztőcsonttal kapcsolatban jóval kevesebb irodalmi adat áll a rendelkezésünkre. A jelen írás a betegség kialakulását valamennyi kéztőcsontra nézve egységesen szándékozik bemutatni.

\section{Kulcsszavak: $\quad$ Csontnekrózis; Csukló; Kéztő;}

B. Kaszap, G. Skaliczki: Development of the avascular necrosis of the carpal bones. Review of the literature

To our recent knowledge, the main etiological factor of the avascular necrosis of the carpal bones is the disturbance of their blood supply, which is a multifactorial disorder itself. Beyond that, there are lots of other factors, which also contribute to the development of the disease. The exact etiology has been unclear for more than 100 years. The most frequently affected bone of the carpus is the lunate ( $\mathrm{m}$. Kienböck), being the subject of several publications. There is much less literature data available about the avascular necrosis of the other carpal bones. The aim of the present review is to sum up the common etiological aspects of the disease for all the carpal bones.

Keywords: $\quad$ Carpal bones - Phisiopathology; Osteonecrosis - Epidemiology; Wrist joint - Etiology; 


\section{BEVEZETÉS}

A holdascsont csontnekrózisának első leírása Robert Kienböck (1871-1953) bécsi radiológustól származik 1910-ből (3). Még ugyanebben az évben Georg Karl Felix Preiser (1876-1913) hamburgi ortopédsebész leírta a sajkacsont traumát követő, de törés nélkül létrejövő nekrózisát. Kevésbé elterjedt, de az irodalomban több helyen fellelhető a fejescsont nekrózisának szerzői neve: Morbus Jönsson. Az egyéb lokalizációk esetében a szerzői nevek csak néhány tankönyvben kerülnek megemlítésre (20). Az egyes kéztőcsontok avascularis nekrózisának szerzői nevei az I. Táblázatban találhatók. A különböző kéztőcsontok érintettségének gyakorisága nagy szórást mutat, ennek magyarázata elsősorban az anatómiai adottságokban keresendő.

I. táblázat Az egyes előfordulási helyeknek megfelelő szerzői nevek [20]

\begin{tabular}{|c|c|}
\hline Az érintett csont & A betegség szerzői neve \\
\hline Os lunatum & Morbus Kienböck \\
\hline Os scaphoideum & Morbus Preiser \\
\hline Os capitatum & Morbus Jönsson \\
\hline Os hamatum & Morbus Vogel \\
\hline Os trapezium & Morbus Harms \\
\hline Os trapezoideum & Morbus Agati \\
\hline Os triquetrum & Morbus Zimmer-Witt \\
\hline Os pisiforme & Morbus Schmier-Meyers \\
\hline
\end{tabular}

\section{Epidemiológia}

A kéz területén a holdascsont avascularis nekrózisa a leggyakoribb. Egy 51.071 beteg radiológiai leleteit kiértékelő amerikai tanulmány szerint a radiológiai prevalencia 270/100.000 fő, de más tanulmányok ettől jelentősen eltérő eredményre jutottak, amelynek hátterében módszertani különbséget sejtenek a szerzők (24). A betegség előfordulási korcsúcsa a 15 . és 40. év közé tehető, és a férfiak kissé gyakrabban érintettek (55\%). A betegség gyermekkorban is előfordulhat, ilyenkor a regenerációs hajlam a felnőttkorinál nagyobb (10). Gyakoriság szempontjából a holdascsontot a sajkacsont követi, ez a megállapítás azonban pontos epidemiológiai adatok híján a szerzők becslésén alapul (36). 1980 és 2011 között összesen 136 dokumentált eset volt fellelhető a szakirodalomban: ezek alapján a betegség kialakulása 42 éves átlagos életkorban (tartomány: 9-76 év) a leggyakoribb, inkább nőknél (58\%) a domináns kézben (66\%) fordul elő (12). Az fejescsont avascularis nekrózisára vonatkozóan egy 2014-es irodalmi áttekintés összesen 48 eset alapján egyelő nemi megoszlást állapított meg (16), míg a horgascsont esetében összesen 12 eset alapján a férfiak gyakoribb érintettségét állapította meg (az esetek 2/3-a) (15). A betegek átlagéletkora a fent említettekhez hasonló volt. A többi kéztőcsont esetében csupán egyedi esetleírások léteznek, itt epidemiológiai adatok egyáltalán nem állnak rendelkezésre.

\section{Etiológia és rizikófaktorok}

A pontos kóroktan a mai napig nem teljesen tisztázott. Sok esetben még az sem állapítható meg, hogy egyetlen, vagy egyszerre több faktor közösen felelős a kialakulásért. A betegség kialakulásának a legnépszerűbb és legkézenfekvőbb magyarázata szerint a csontelhalás közvetlenül a lokális vérellátás elégtelenségére, elsősorban a kisebb artériák szűkületére, illetve elzáródására vezethető vissza $(3,4)$.

A carpalis régió artériás vérellátása felosztható extraossealis és intraossealis szakaszra. A proximalis kéztőcsontokat főleg az arcus 
palmaris profundus ágai látják el retrográd módon (4). Panagis és munkatársai a kéztő vérellátását vizsgálva az avascularis nekrózis kialakulásának szempontjából három csoportba sorolták a kéztőcsontokat (II. Táblázat) (14). A csontokat ellátó erek extraossealis szakasza általában anastomosisok által biztosított, egy-egy ér izolált elzáródása ezért itt még nem feltétlenül jelent komoly problémát. Feltételezik, hogy a csontnekrózist kiváltó elzáródások főleg intraossealisak, vagy közvetlenül az ér csontba való belépésénél találhatók (4). A sajkacsont proximalis pólusának vérellátottsága kimondottan gyér. A holdascsont a méretéhez képest nagy ízfelszínnel rendelkezik, üvegporcborítással bír szinte minden irányban. A foramina nutritica a fennmaradó porcmentes területen található, az esetek $80 \%$ ában palmarisan és dorsalisan, ám 20\%-ában csak palmarisan (14). Ha az utóbbi esetben ez az egyetlen artéria valamilyen okból elzáródik, a csont elhal: ezt a betegségre hajlamosító variánsnak tekintjük. A fejescsont vérellátása többek szerint retrográd módon történik (4), mások a proximalis rész direkt vérellátását is leírták (1).

A kéztőcsontok vérellátása tehát egyénenként különbözhet. Az erről rendelkezésre álló tudásunk néhány viszonylag kis esetszámú publikációra alapul, amelyek állításai közt nem ritka a diszkrepancia $(4,14)$. Egyes anatómiai variánsok nem adnak lehetőséget bizonyos ellátási területek anastomosisok általi „bebiztosítására”, itt az érszakasz elzáródása nekrózist von maga után.

$\mathrm{Az}$ artériák falának laesiója vagy thromboticus elzáródása a kéztőcsontok esetében is előfordulhat, így kórokként szerepelhet (17). A "csont kompartment szindrómája” elmélet szerint pedig a csontszöveti ischaemia során kialakuló intraossealis ödéma és a csontvelői zsírsejtek megduzzadása a csont szinuszoidjainak relatív beszúkülése által a vérelvezetés csökkenését okozzák, ami vénás pangást és az intraossealis nyomás növekedését idézi elő (2). Morbus Kienböck esetén valóban gyakran emelkedett intraossealis nyomás mérhető, ugyanezt átmenetileg elő lehet idézni a csukló végállású extenziójával is (feltehetően a vérelvezetés extraossealis vénakompresszió általi átmeneti csökkentése miatt (19).

Hulten 1928-as publikációja óta él az elmélet, amely szerint negatív ulna variáns esetén a "túl rövid" singcsont miatt axialis terhelés esetén (különösen ulnarductio során) a holdascsont a radius distalis ízfelszínének éles ulnaris szélén támaszkodik meg, ami által a proximalis csontlemezét koncentrált erőbehatás éri, és ez hozzájárul a csont nekrózisának a kialakulásához (2). Milyen gyakran fordul elő a negatív ulna variáns az átlagpopulációban? Van Leeuwen és munkatársai 166 Kienböck kóros beteg csuklóröntgenét ugyanennyi egészségesével vetette össze: a negatív ulna variáns gyakorisága Kienböck kór esetén 93\% volt, míg egészségesekben 89\%; megállapították, hogy statisztikai szempontból van összefüggés a negatív ulna variáns és a betegség jelenléte közt, még ha enyhe is. Számos más publikáció azonban nem tudott bizonyítani ilyen összefüggést, az elmélet manapság erősen vitatott (25). Megjegyzendő, hogy a holdascsont proximalisulnaris részén lokális terhelésnövekedést okozhat a pozitív ulna variáns is, amikor a „túl hosszú" singcsont distalis vége közvetlen nyomást gyakorol a holdascsontra: ezt az állapotot azonban ulnocarpalis impactio szindróma néven külön tárgyaljuk a Kienböck betegségtől (21).

Maga az érintett kéztőcsont geometriájának anatómiai variánsai is kóroktani jelentőséggel bírhatnak. A holdascsont esetében például Thienpont és munkatársai szerint a kisebb csontméret, a csont nagyobb radialis inklinációja és a radius distalis ízfelszínének AP síkban nézett laposabb inklinációja hajlamosítottak a Kienböck kór kialakulására, amelynek hátterében a megnövekedő mechanikai terhelést sejtik (23). Zapico 1966-ban a holdascsont proximalis és radialis oldalainak konvergenciája alapján három típust különített el (13):

- I.: (13-49\%.) Trapezoid forma; a két oldal által bezárt szög $\mathrm{kb}$. $130^{\circ}$. Az éles szögben megtörő trabecularis szerkezet viszonylag gyenge. A fő terhelés holdcsont radialis felét éri. Gyakran negatív ulna variánssal fordul együtt elő.

- II.: (23-62\%.) Köbös forma; a két nevezett oldal által bezárt szög kb. $100^{\circ}$. Gyakran neutrális ulna variánssal együtt fordul elő.

- III.: (14-34\%) itt nincs a csontnak radialis oldala, hanem két (ulnaris, illetve radialis 
irányba néző, V-betǔt formáló) proximalis ízfelszíne. Gyakran pozitív ulna variánssal együtt fordul elő.

Viegas és munkatársai kétféle holdascsont formát különböztetett meg a csont distalis ízfelszíne alapján, amelyhez eltérő szalagos rögzítés, és biomechanikai tulajdonságok társulnak $(13,22)$ :

- I.: Distalisan egyetlen ízületet alkot (a fejescsonttal), nem ízesül a horgascsonttal. Radialductio során a sajkacsont mozgásában a transzláció dominál (5). A fejescsont ennél a típusnál inkább radialis, a holdascsont pedig inkább ulnaris pozíciójú: ez utóbbi rontja a holdascsont proximalis ízületi fedettségét (2).

- II.: a csontnak két ízfelszíne van a distalis pólusán: egy a horgascsonttal is ízesül. Radialductio során az utóbbi a carpus transzlációját akadályozza, a scaphoideum mozgásában ezért a flexió/extenzió dominál (5). A típus gyakorisága az átlagpopulációban 44-73\%, de Kienböck kór esetén csak 24,5\%: a betegség által „ritkábban sújtott" variánsnak túnik (22).

A többi kéztőcsont esetében nem található a formai variánsokra, mint potenciális rizikófaktorra vonatkozó adat.

A következő alapbetegségek esetén avascularis csontnekrózis szekunder formájáról beszélhetünk: a zsír anyagcseréjének zavarai (pl. Gaucher-kór), máj anyagcserezavarok, diabates mellitus, köszvény, magas vérnyomás, különböző thrombophíliák (artériás embolizáció miatt), keszonbetegség (nitrogénembolizáció miatt), generalizált arteriosclerosis, különböző anémiák, akut leukémia, szisztémás kötőszöveti betegségek, például lupus erythematodes, szisztémás vasculitisek, glomerulopathiák, vesetranszplantáció utáni állapot, krónikus polyarthritis. A betegség kialakulásának legfontosabb rizikófaktorainak általában a következőket tekintik: szisztémás kortikoszteroid terápia (főleg nagy egyszeri dózisok vagy hosszú távú alkalmazás esetén), kemoterápia, káros szenvedélyek (dohányzás, alkoholabúzus, drogok), és repetitív mikrotraumák (pl. a vibrációnak való kitettség építőmunkások esetében a légkalapács és ütve fúró rendszeres használata során) $(4,7,9,12,17)$. A sugárterápia is okozhat csontnekrózist, de a kéztő csontjait érintő esetet nem találni az irodalomban.

Csonttörés esetén a törési résnél az erek megsérülhetnek, vagy pedig a törés dislocatiója a csontot ellátó extraossealis erek kompreszszióját okozza. Elméletileg bármely kéztőcsont törése kiválthat szekunder osteonecrosist, az azonban csontonként változó, hogy ez menynyire gyakori kiváltó oka az adott csont nekrózisának. A kéztő csontjai közül a sajkacsont törése fordul elő a legtöbbször, egyben a törést tartják a sajkacsont avascularis nekrózisáért leggyakrabban felelős oknak. A proximalis pólus törését követően az esetek 14-100\%-ában számoltak be avascularis nekrózis kialakulásáról, míg a csont középső harmadának törése után az esetek 30-50\%-ában (4). A m. Preiser esetében differenciáldiagnosztikai szempontból az álízület képződéstől való elkülönítés okozhat nehézséget; a besorolás még alapos radiológiai elemzés és anamnézisfelvétel után sem mindig egyértelmú (3). A fejescsont és horgascsont osteonecrosisának hátterében is leggyakrabban a trauma áll $(4,9,15)$. Az, hogy hasonló (retrográd) vérellátásuk ellenére a fejescsont avascularis nekrózisa a holdascsonténál és a sajkacsonténál ritkábban fordul elő, valószínúleg a csont jobb mechanikai védettségének köszönhető (9). Traumás eredete ellenére primer avascularis csontnekrózisként sorolható be a foglalkozás vagy sport során elszenvedett repetitív mikrotraumák okozta betegség: itt feltehetően okkult stressz-fraktúrák károsítják a csont vérellátását (8). 
II. táblázat A kéztőcsontok csoportosítása artériás vérellátásuk alapján Panagis et al. szerint. [14]

\begin{tabular}{|c|c|c|}
\hline I. csoport & II. csoport & III. csoport \\
\hline $\begin{array}{ll}\text { - } & \text { sajkacsont } \\
\text { - } & \text { holdascsont } \\
\text { (az esetek 20\%-ában) } \\
\text { - fejescsont }\end{array}$ & $\begin{array}{l}\text { - } \text { kis trapézcsont } \\
\text { - horgascsont }\end{array}$ & $\begin{array}{ll}\text { - } & \text { trapézcsont } \\
\text { - } & \text { háromszögletû́ csont } \\
\text { - } & \text { borsócsont } \\
\text { - } & \text { holdascsont } \\
& \text { (az esetek } 80 \% \text {-ában) }\end{array}$ \\
\hline $\begin{array}{l}\text { A csont nagy részét egyetlen } \\
\text { intraossealis ér látja el. }\end{array}$ & $\begin{array}{c}\text { A csontba két különböző } \\
\text { helyen érkeznek az ellátó } \\
\text { erek. Nincsenek intraossealis } \\
\text { anastomosisok. }\end{array}$ & $\begin{array}{c}\text { A csontba két különböző } \\
\text { helyen érkeznek az ellátó } \\
\text { erek. Vannak intraossealis } \\
\text { anastomosisok. }\end{array}$ \\
\hline $\begin{array}{c}\text { Az avascularis nekrózis veszé- } \\
\text { lye törést követően viszonylag } \\
\text { nagy. }\end{array}$ & \multicolumn{2}{|c|}{$\begin{array}{l}\text { Az avascularis nekrózis veszélye törést követően viszonylag } \\
\text { alacsony. }\end{array}$} \\
\hline
\end{tabular}

\section{Az betegség lefolyása}

A betegség kezdeti és köztes fázisaiban a csontszövetpusztulás nem jár egyedül: az ép és a necroticus szövetrészek határán egy úgynevezett átmeneti, illetve reparatív zónában egyidejüleg regenerációs folyamatok zajlanak, ami a klinikai gyakorlatban i.v. gadolínium alapú kontrasztanyaggal végzett MRI perfúzióanalízissel mutatható jól ki. Ide az ép vérellátású területek felöl erek törnek be (revascularisatcio) és a kialakuló sarjszövet fokozatosan átveszi a necroticus csontosállomány helyét (21). Az egyes zónák általában sávosan különülnek el egymástól:

- necroticus zóna (jellemzően a csont proximalis pólusánál)

- reparatív zóna (jellemzően a középső sávban)

- vitális zóna (jellemzően a csont distalis pólusánál)

Ez az elrendeződés a retrográd vérellátás miatt általában mind a holdas-, mind pedig a sajka- és fejescsont avascularis nekrózisánál megfigyelhető (21). Míg a necroticus csontszövet scleroticus elváltozásokat mutat, a reparatív zónában a demineralizáció a jellemző. Az utóbbi esetben csontreszorpció átmenetileg helyi osteopeniát okoz, ami a patológiás törések kialakulásának kedvezhet $(2,8,21)$.
Ha a meggyengült csontszövet nem tud ellenállni a terhelésnek, akkor mikrofraktúrák vagy ritkábban egyetlen törésvonal alakul ki. A csont megroppanása fontos vízválasztó az egyes klasszifikációk és terápiás stratégiák szempontjából, hiszen a betegség eddig a pontig mondható potenciálisan reverzibilisnek (11).

A holdascsont deformációja a fejescsont proximalis vándorlását okozza, a sajkacsont pedig flexiós állásba kerül (1. ábra). Ez az instabilitás kezdetben flexibilis, később a lágyrészek megrövidülése miatt rigiddé válik (2). $\mathrm{Ha}$ kialakul a kéztő magasságcsökkenése (angolul „carpal collapse”), akkor megváltozik a kéztő terhelése és a távolabb eső helyeken is patológiás elváltozások alakulhatnak ki, végső soron pedig kiterjedt arthrosissal lehet számolni. Kezelés nélkül az esetek többségében az első diagnózist követő 4-5 évben kialakul a manifeszt csuklóarthrosis (18). A sajkacsont esetében a kiváltó ok legtöbbször valamilyen trauma. $\mathrm{Ha}$ a törést nem látják meg a röntgenen, könynyen deklarálhatják az esetet Preiser kórnak. A betegség leggyakrabban a csont proximalis pólusát érinti (7). A fejescsont avascularis nekrózisa során szintén leggyakrabban a proximalis pólus érintett: előbb-utóbb elveszíti az eredeti formáját és támasztó szerepét, ezért a horgascsont a fejescsont distalis részével együtt radialis irányba mozdul el, és radialis 
irányú nyomást gyakorol a sajkacsontra, azt flexiós állásba kényszerítve (16). A horgascsont avascularis nekrózis által leggyakrabban érintett része szintén a proximalis pólus, de a csonttest kollapszusát még a biztos diagnózis ellenére sem figyelték meg soha (15).

Mivel az ízületi porcot elsődlegesen az ízületi folyadék táplálja, a porcszövet nincs közvetlenül ráutalva az alatta található csontszövet ép vérellátására (26). Porckárosodás ennek megfelelően igazán csak akkor lép fel, ha megváltozik az alatta lévő csontfelszín kontúrja. Gondot okozhat az elkülönítés az egyéb osteochondralis defektust okozó entitásoktól (osteochondrosis dissecans, előrehaladott arthrosis, subchondralis inszufficiencia-törés, akut osteochondralis törés), ugyanis igen nagy az átfedés ezek radiológiai megjelenése közt: egyazon radiológiai kép, különböző vizsgálók interpretálásában más-más diagnózishoz vezethet (6). Ha az aszeptikus csontnekrózis gyermekkorban lép fel, akkor általa az érintett porc természetesen nem csak ízületi porc lehet, hanem növekedési is: ilyenkor a csontnövekedés zavara fenyeget (9).

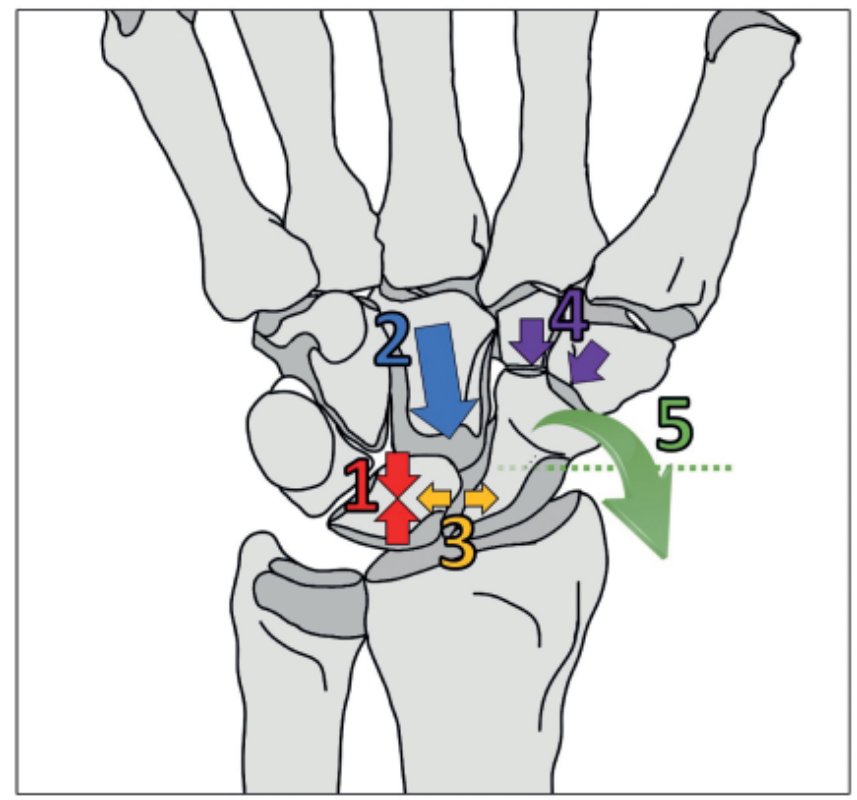

1. ábra

A holdascsont nekrózisának elörehaladott állapotánál fellépő carpalis kollapszus

A holdascsont megroppanása (1) a fejescsont proximalis vándorlását (2) okozza. Az os trapezium és trapezoideum felöl érkezö terhelés (4) a sajkacsontot flexiós állásba igyekszik kényszeríteni (5). A proximalis irányba elmozduló fejescsont (2) a holdas- és sajkacsont közé igyekszik beékelődni, és e kettőt egymástól eltávolítani (3). A kialakuló scapholunáris instabilitás a holdascsont enyhe extenzióját okozza és tovább erősíti a sajkacsont patológiás flexióját (5). [2]

\section{MEGBESZÉLÉS}

$\mathrm{Az}$ avascularis csontnekrózis a kéztő több csontját érintheti, leggyakrabban azonban a holdascsontot, utána pedig a sajkacsontot. A pathomechanizmus fontosabb elemei minden kéztőcsont esetében megegyeznek, ez segítséget nyújthat azon kéztőcsontok esetében is, ahol kevés irodalmi adat áll a rendelkezésre. Multifaktoriális megbetegedésről van szó, amelynél az egyes kiváltó faktorok súlya - még ha ugyanarról a csontról is van szó - esetenként változó lehet. A leghatékonyabb terápia kiválasztásához minden esetben fontos a lehetséges kiváltó okok számbavétele. A képalkotó diagnosztika helyes interpretációja pedig a betegség lefolyásának általános ismeretére alapul. A betegség klinikai managementjének sikere tehát teljes mértékben fentebb taglalt összefüggések ismeretétől függ. 


\section{IRODALOM}

1. Almquist E. E.: Capitate shortening in the treatment of Kienbock's disease. Hand Clin. 1993. 9. (3): 505-512.

2. Bain G. I., MacLean S. B., Yeo C. J., Perilli E., Lichtman D. M.: The etiology and pathogenesis of Kienbock Disease. J. Wrist Surg. 2016. 5. (4): 248-254. https://doi.org/10.1055/s-0036-1583755

3. Betz C., Mehling I. M., Sauerbier M.: Knochennekrosen der Hand. Z. Orthop. Unfall. 2015. 153. (4): $441-454$. https://doi.org/10.1055/s-0035-1546236

4. Botte M. J., Pacelli L. L., Gelberman R. H.: Vascularity and osteonecrosis of the wrist. Orthop. Clin. North Am. 2004. 35. (3): 405-421. https://doi.org/10.1016/i.ocl.2004.04.004

5. Galley I., Bain G. I., McLean J. M.: Influence of lunate type on scaphoid kinematics. J. Hand Surg. Am. 2007. 32. (6): 842847. https://doi.org/10.1016/i.jhsa.2007.03.012

6. Gorbachova T., Melenevsky Y., Cohen M., Cerniglia B. W.: Osteochondral lesions of the knee: Differentiating the most common entities at MRI. Radiographics. 2018. 38. (5): 1478-1495. https://doi.org/10.1148/rg.2018180044

7. Herbert T. J., Lanzetta M.: Idiopathic avascular necrosis of the scaphoid. J. Hand Surg. Br. 1994. 19. (2): 174-182. https://doi.org/10.1016/0266-7681(94)90159-7

8. Hughes J. M., Popp K. L., Yanovich R., Bouxsein M. L., Matheny R. W., Jr.: The role of adaptive bone formation in the etiology of stress fracture. Exp. Biol. Med. (Maywood). 2017. 242. (9): 897-906. https://doi.org/10.1177/1535370216661646

9. Humphrey C. S., Izadi K. D., Esposito P. W.: Case reports: osteonecrosis of the capitate: a pediatric case report. Clin. Orthop. Relat. Res. 2006. 447. 256-259. https://doi.org/10.1097/01.blo.0000203459.12759.29

10. Kalb K., Pillukat T., Schmitt R., Prommersberger K. J.: Die Lunatumnekrose im Kindes- und Jugendalter. Handchir. Mikrochir. Plast. Chir. 2010. 42. (3): 187-197. https://doi.org/10.1055/s-0030-1249684

11. Kijima Y., Viegas S. F.: Wrist anatomy and biomechanics. J Hand Surg Am. 2009. 34. (8): 1555-1563. https://doi. org/10.1016/j.jhsa.2009.07.019

12. Lenoir H., Coulet B., Lazerges C., Mares O., Croutzet P., Chammas M.: Idiopathic avascular necrosis of the scaphoid: 10 new cases and a review of the literature. Indications for Preiser's disease. Orthop. Traumatol. Surg. Res. 2012. 98. (4): $390-397$. https://doi.org/10.1016/j.otsr.2011.11.013

13. Mauler F., Beaulieu J. Y.: Morphological associations between the distal radioulnar joint and the lunate. J. Wrist Surg. 2018. 7. (2): 148-155. https://doi.org/10.1055/s-0037-1607327

14. Panagis J. S., Gelberman R. H., Taleisnik J., Baumgaertner M.: The arterial anatomy of the human carpus. Part II: The intraosseous vascularity. J. Hand Surg. Am. 1983. 8. (4): 375-382. https://doi.org/10.1016/s0363-5023(83)80195-6

15. Peters S. J., Verstappen C., Degreef I., Smet L. D.: Avascular necrosis of the hamate: three cases and review of the literature. J. Wrist Surg. 2014. 3. (4): 269-274. https://doi.org/10.1055/s-0034-1394135

16. Peters S. J., Degreef I., De Smet L.: Avascular necrosis of the capitate: report of six cases and review of the literature. J. Hand Surg. Eur. Vol. 2015. 40. (5): 520-525. https://doi.org/10.1177/1753193414524876

17. Petsatodis E., Ditsios K., Konstantinou P., Pinto I., Kostretzis L., Theodoroudis I., Pilavaki M.: A case of trapezium avascular necrosis treated conservatively. Case Rep. Orthop. 2017. 2017. 6936013. https://doi.ora/10.1155/2017/6936013

18. Schiltenwolf M., Martini A.: Der Spontanverlauf der Lunatumnekrose. Orthopäde. 1994. 23. (3): 243-248.

19. Schiltenwolf M., Martini A. K., Mau H. C., Eversheim S., Brocai D. R., Jensen C. H.: Further investigations of the intraosseous pressure characteristics in necrotic lunates (Kienbock's disease). J. Hand Surg. Am. 1996. 21. (5): 754-758. https://doi.org/10.1016/s0363-5023(96)80187-0

20. Schiltenwolf M.: Osteochondrodysplasien - Osteonekrosen des Ellenbogens und Handgelenks. In: Martini A. K. (szerk.): Ellenbogen, Unterarm, Hand. Stuttgart. Thieme. 2003. 233-246. p. https://doi.org/10.1055/b-0033-2421

21. Schmitt R., Kalb K.: Bildgebende Diagnostik der Lunatumnekrose. Handchir. Mikrochir. Plast. Chir. 2010. 42. (3): $162-170$. https://doi.org/10.1055/s-0030-1253433

22. Tatebe M., Shinohara T., Okui N., Yamamoto M., Kurimoto S., Hirata H.: Arthroscopic lunate morphology and wrist disorders. Surg. Radiol. Anat. 2013. 35. (1): 79-83. https://doi.org/10.1007/s00276-012-0991-2

23. Thienpont E., Mulier T., Rega F., De Smet L.: Radiographic analysis of anatomical risk factors for Kienbock's disease. Acta Orthop. Belg. 2004. 70. (5): 406-409.

24. van Leeuwen W. F., Janssen S. J., ter Meulen D. P., Ring D.: What is the radiographic prevalence of incidental Kienbock Disease? Clin. Orthop. Relat. Res. 2016. 474. (3): 808-813. https://doi.orq/10.1007/s11999-015-4541-1

25. van Leeuwen W. F., Oflazoglu K., Menendez M. E., Ring D.: Negative ulnar variance and Kienbock Disease. J Hand Surg Am. 2016. 41. (2): 214-218. https://doi.org/10.1016/i.jhsa.2015.10.014

26. Wang Y., Wei L., Zeng L., He D., Wei X.: Nutrition and degeneration of articular cartilage. Knee Surg Sports Traumatol Arthrosc. 2013. 21. (8): 1751-1762. https://doi.org/10.1007/s00167-012-1977-7

\section{Dr. Kaszap Balázs}

Klinik für Handchirurgie, Rhön-Klinikum AG

D-97616 Bad Neustadt a. d. Saale, Von-Guttenberg-Straße 11

E-mail: kaszapb@gmail.com 